УдК 616.314.11:616-74.004.67]-036-083

DOI 10.11603/2311-9624.2017.2.7963

\author{
(CЕ. В. Безвушко, О. О. Шпотюк
}

Львівський національний медичний університет імені Данила Галицького

\title{
Клінічна оцінка реставрацій із композитних матеріалів 3 урахуванням гігієни порожнини рота
}

Резюме. У статті описано клінічну ефективність реставрацій, які виконали композиційними матеріалами для відновлення твердих тканин зубів. Оцінили стан реставрацій у дітей із різним рівнем гігієни порожнини рота. Вплив гігієни на стан пломб через 3; 6; 12 місяців.

Мета дослідження - клінічно оцінити якість реставрацій жувальних зубів, виконаних із композиційних матеріалів з урахуванням гігієни порожнини рота.

Матеріали і методи. Обстежено 92 дитини віком 12-17 років, у яких було відновлено композиційними матеріалами 128 зубів із каріозними дефектами 1 класу за Блеком. Для відновлення дефектів використовували композитні матеріали «Charisma», «Dipol» та «Esta-3» світлового твердіння.

Результати досліджень та їх обговорення. У дітей із поганою гігієною порожнини рота показники якості пломб погіршені для всіх матеріалів порівняно з дітьми із хорошою та задовільною гігієною порожнини рота. Особливо збільшується кількість зубів із порушенням крайової адаптації, невідповідністю кольору, дискомфортом та крайовою пігментацією. Необхідно зауважити, що порушення анатомічної форми реставрацій (6,9%), поява шороховатості (8,6 \%), порушення кольору (10,6 \%) та поява пігментацій (17,7 \%) значно частіше виявлені в каріозних дефектах, відновлених матеріалом «Dipol». При поганій гігієні порожнини рота більш часто діагностовано порушення анатомічної будови реставрацій із композиту «Charisma» (2,3 \%) та матеріалу «Esta-3» (5,9 \%) порівняно 3 дітьми 3 хорошою та задовільною гігієною порожнини рота.

Висновки. Оцінка якості реставрацій жувальної групи зубів композитними матеріалами показала, що рівень гігієни порожнини рота суттєво впливає на якість пломб.

Ключові слова: реставрації; функціонування; пломбування; жувальна група зубів; гігієна порожнини рота; фізичні властивості реставрацій.

\section{(СЭ. В. Безвушко, О. О. Шпотюк}

Львовский национальный медицинский университет имени Данила Галицкого

\section{Клиническая оценка реставраций с композитных материалов с учетом гигиены полости рта}

Резюме. В статье описано клиническую эффективность реставраций, выполненных композиционными материалами для восстановления твердых тканей зубов. Оценили состояние реставраций у детей с различным уровнем гигиены полости рта. Влияние гигиены на состояние пломб через 3; 6; 12 месяцев.

Цель исследования - клинически оценить качество реставраций жевательных зубов, выполненных из композиционных материалов с учетом гигиены полости рта.

Материалы и методы. Обследовано 92 ребенка в возрасте 12-17 лет, у которых было восстановлено композиционными материалами 128 зубов с кариозными дефектами 1 класса по Блэку. Для восстановления дефектов использовали композитные материалы «Charisma», «Dipol» и «Esta-3» светового отверждения.

Результаты исследований и их обсуждение. У детей с плохой гигиеной полости рта показатели качества пломб ухудшены для всех материалов по сравнению с детьми с хорошей и удовлетворительной гигиеной полости рта. Особенно увеличивается количество зубов с нарушением краевой адаптации, несоответствием цвета, дискомфортом и краевой пигментацией. Следует заметить, что нарушение анатомической формы реставраций (6,9%), появление шероховатости (8,6 \%), нарушение цвета (10,6 \%) и появление пигментаций $(17,7$ \%) значительно чаще обнаружены в кариозных дефектах, восстановленных материалом «Dipol». При плохой гигиене полости рта более часто диагностировано нарушение анатомического строения реставраций с композита «Charisma» (2,3 \%) и материала «Esta-3» (5,9%) по сравнению с детьми с хорошей и удовлетворительной гигиеной полости рта. 
Выводы. Оценка качества реставраций жевательной группы зубов композитными материалами показала, что уровень гигиены полости рта существенно влияет на качество пломб.

Ключевые слова: реставрации; функционирования; пломбирование; жевательная группа зубов; гигиена полости рта; физические свойства реставраций.

\author{
CE. V. Bezvushko, O. O. Shpotyuk \\ Danylo Halytskyi Lviv National Medical University
}

\title{
Clinical evaluation of composite restorations based on oral hygiene
}

Summary. The article describes the clinical effectiveness of restorations performed by composite materials for the restoration of hard tissues of teeth; evaluates the status of restorations in children with different levels of oral hygiene; influence of hygiene on the state of seals in 3, 6, 12 months.

The aim of the study - to assess clinically the quality of restorations of chewing teeth made of composite materials with regard to oral hygiene.

Materials and Methods. A total of 92 children aged 12-17 years were examined in whom 128 teeth with caries defects type I according to Black were reconstructed with composite materials. To repair the defects, composite materials Charisma, Dipol and Esta-3 light curing were used.

Results and Discussion. In children with poor oral hygiene, the quality of the seals is deteriorated for all materials compared to children with good and satisfactory oral hygiene. Especially the number of teeth with violation of marginal adaptation, discrepancy of color, discomfort and marginal pigmentation increases. It should be noted that the disruption of the anatomical form of the restorations (6.9\%), the appearance of roughness $(8.6 \%)$, color disturbance $(10.6 \%)$ and the appearance of pigmentation (17.7 \%) were detected more often in caries defects, Dipol. With poor oral hygiene, the violation of the anatomical structure of the restorations from the Charisma composite (2.3 \%) and the Esta-3 material (5.9\%) is more often compared with children with good and satisfactory oral hygiene.

Conclusions. Thus, the evaluation of the quality of restorations of the chewing group of teeth with composite materials showed that the level of oral hygiene significantly affects the quality of the fillings.

Key words: restoration; functioning; filling; chewing group of teeth; oral hygiene; physical properties of restorations.

Вступ. У запропонованих системах оцінки критеріїв якості реставрацій каріозних уражень композитами, які, відповідно до протоколів надання стоматологічної допомоги, пов’язують термін їх функціонування, впродовж якого збережена цілісність та функціональна придатність реставрації [2]. Згідно 3 даними [3], забезпечення гарантійної придатності реставрацій залежить від багатьох чинників. Зокрема, чинники ризику можуть бути значною мірю зумовлені самим технологічним процесом підготовки каріозних порожнин до реставрацій, порушенням техніки пломбування або використання адгезивних систем, індивідуальною чутливістю до композиту, а також умовами порожнини рота. Серед місцевих чинників важливу роль у забезпеченні якості реставрацій відіграють морфологічні, хімічні, фізичні властивості твердих тканин зубів, резистентність емалі, гомеостаз, мікробіологічні властивості ротової рідини та гігієна порожнини рота $[4,5]$.
Клінічні дослідження свідчать, що найбільш частими проблемами стають порушення крайового прилягання пломб, забарвлення межі матеріалу з тканинами зуба, рецидивний карієс унаслідок поганої гігієни порожнини рота[1, 7-9]. Разом з тим, поодинокі дослідження не дозволяють достатньою мірою оцінити вплив чинників ризику на функціонування реставрацій та забезпечення їх якості.

Метою дослідження було клінічно оцінити якість реставрацій жувальних зубів, виконаних із композиційних матеріалів з урахуванням гігієни порожнини рота.

Матеріали і методи. Обстежено 92 дитини віком 12-17 років, у яких було відновлено композиційними матеріалами 128 зубів із каріозними дефектами 1 класу за Блеком. Для відновлення дефектів використовували композитні матеріали «Charisma», «Dipol» та «Esta-3» світлового твердіння. Залежно від виду композиційного матеріалу, дітей поділили на три групи наступним чином: 30 дітей, у 
яких 42 зуби було запломбовано матеріалом «Charisma», 30 дітей, яким запломбовано 44 зуби матеріалом «Dipol» та у 32 дітей відновлено 42 зуби матеріалом «Esta-3».

Оцінку стану пломб проводили за модифікованим критерієм USPHS для клінічної оцінки реставрацій (Ryge, 1998) [6]. Гігієнічний стан порожнини рота оцінювали за допомогою спрощеного індексу Green-Vermillion (1964). Гігієну порожнини рота визначали перед проведенням реставрацій, після професійної гігієни порожнини рота та при контрольних оглядах, які проводились через 3; 6; 12 місяців. При первинному огляді дітей та їх батьків навчали правилам гігієни порожнини рота.

Результати досліджень та їх обговорення. Результатати обстеження дітей через 3 місяці показали, що анатомічна форма реставрацій жувальної групи всіх зубів збережена, поверхня гладка, змін кольору не виявлено, лише в одному випадку реставрації із композиту «Esta-3» діагностовано незначну чутливість. Хороша гігієна порожнини рота виявлена у значної більшості дітей і склала в середньому $84,7 \%$, задовільна - у 5,5 \%, незадовільна у 4,1 \% та погана - у 5,7 \% обстежених дітей.
Враховуючи, що не виявлено жодних ускладнень після відновлення каріозних порожнин композиційними матеріалами та хорошу гігієну порожнини рота у більшості дітей через 3 місяці спостережень, в подальшому аналіз результатів проводився через 6 і 12 місяців.

Обстеження дітей показали, що через 6 місяців у середньому в 68,1 \% дітей виявлено хорошу гігієну порожнини рота, у 9,7 \% - задовільну, незадовільну і погану склали 8,3 та 13,8 \%. Аналіз гігієнічного стану порожнини рота 3 урахуванням виду композиту показав, що у дітей, в яких відновлені дефекти зубів композитом «Charisma», хорошу гігієну виявлено у 37,5 \%, що значно більше, порівняно 3 дітьми, у яких дефекти відновлені композитом «Dipol» (29,2 \%) та «Esta-3» (33,4 \%) (рис. 1). Незадовільна гігієна порожнини рота була у дітей частіше, каріозні дефекти у яких відновлені матеріалами «Dipol» (33,3 \%) та «Charisma» (29,1 \%). При обстеженні встановлено, що 16,6 \% дітей, у яких каріозні порожнини відновлені композитом «Esta-3» та 15,8 \% «Charisma», мали поганий гігієнічний стан ротової порожнини, що дещо частіше, порівняно 3 дітьми, у яких дефекти відновлені композитом «Dipol» (12,5 \%).

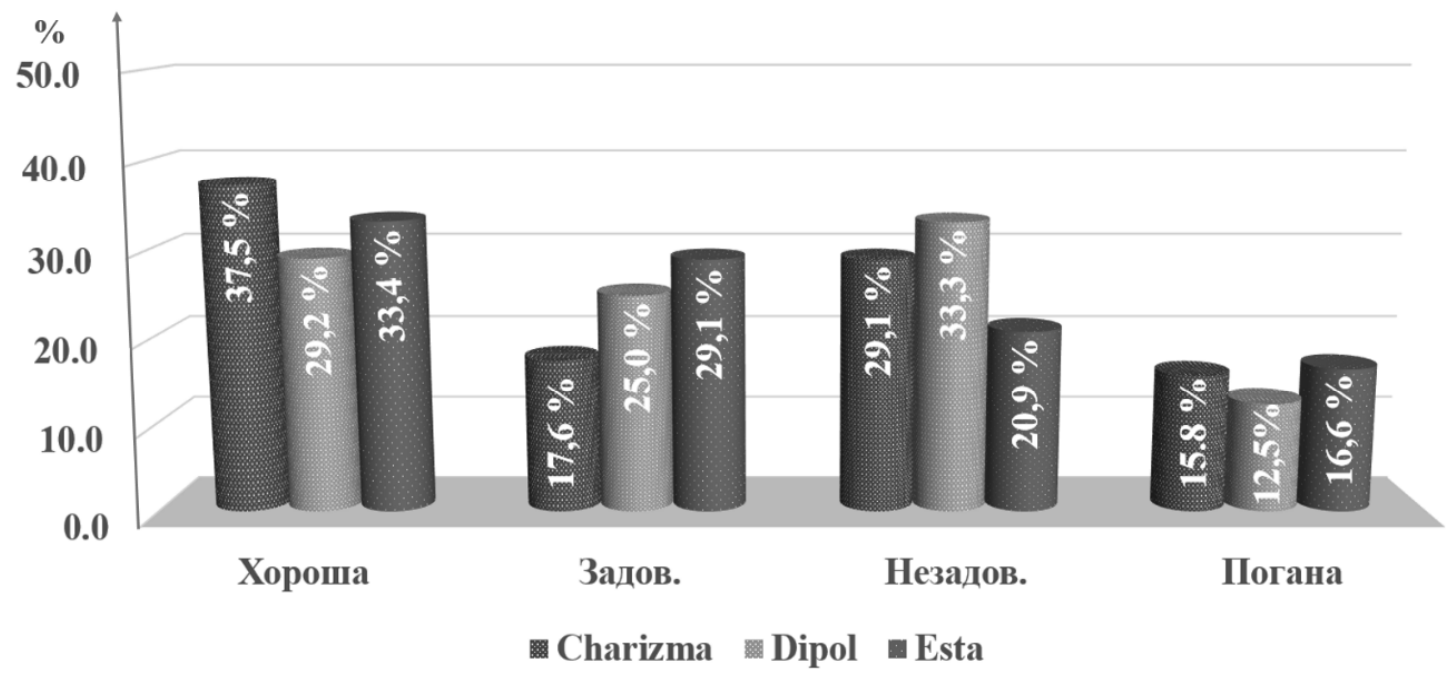

Puc. 1. Рівень гігієни порожнини рота у дітей через 6 місяців (у \%).

Обстеження дітей через 12 місяців показали, що у середньому в 34,78 \% виявлено хорошу гігієну порожнини рота, у $35,7 \%$ - задовільну, в 21,4 \% - незадовільну та у 8,6 \% - погану. Слід зауважити, що значно зменшилася кількість дітей із хорошою гігієною (в 1,9 раза) та 3 поганою (в 1,6 раза), порівняно з даними за 6 місяців.
При порівнянні гігієнічного стану порожнини рота дітей, у яких дефекти твердих тканин відновлені різними композиційними матеріалами, виявлено, що кількість дітей із хорошою гігієною збільшилась в 1,2 раза, у яких пломби 3 композиту «Charisma", та значно зменшилась 3 матеріалу «Dipol» (в 1,4 раза) та «Esta-3» (в 1,3 раза). У 1,5 раза збільшилась кількість ді- 
тей із задовільною гігієною порожнини рота, у яких каріозні дефекти відновлені компози- том «Dipol», та в 1,5 з поганою гігієною при відновленні композитом «Esta-3» (рис. 2).

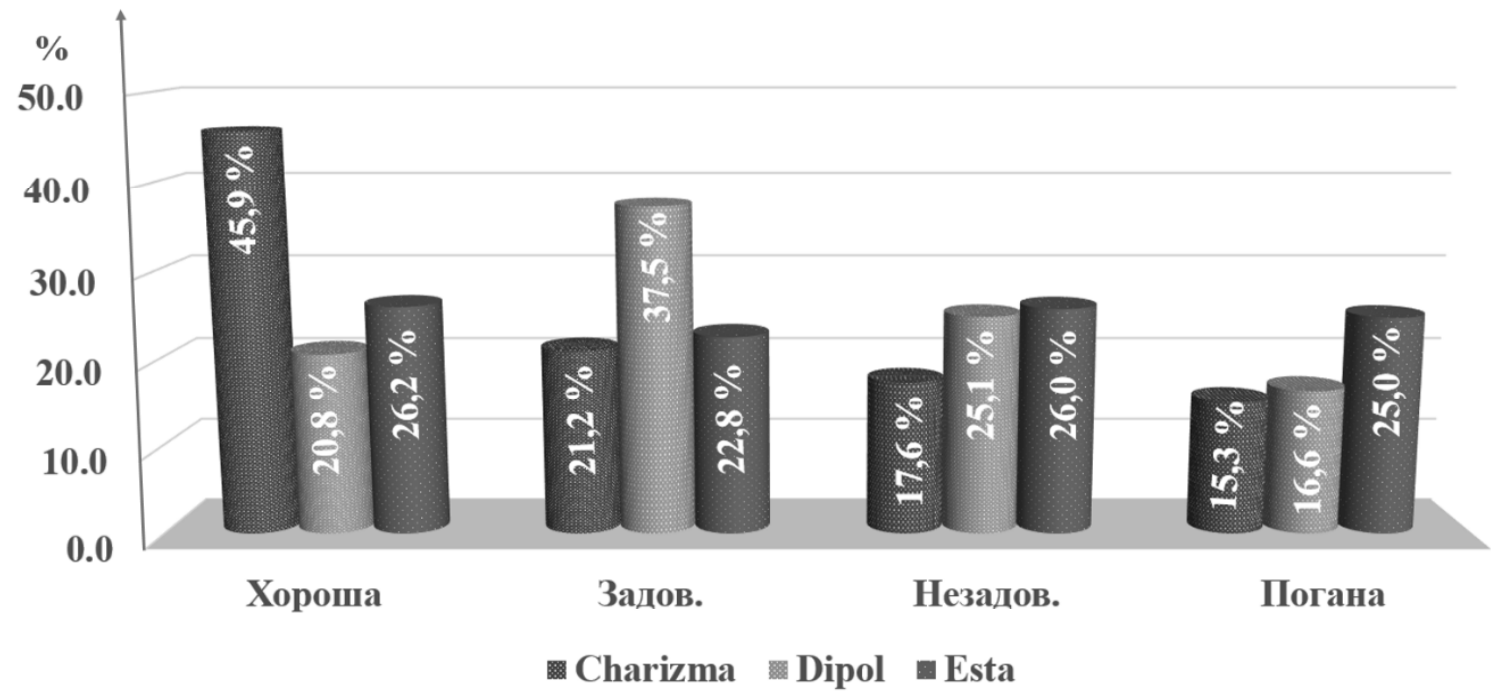

Puc. 2. Рівень гігієни порожнини рота у дітей через 12 місяців.

У подальшому досліджено терміни та якість функціонування реставрацій жувальних зубів при різних рівнях гігієни порожнини рота. Результати дослідження через 12 місяців наведено в таблицях 1-3.

При оцінці стану реставрацій у дітей із хорошою гігієною порожнини рота встановлено, що анатомічна форма збережена у 98,9 \% зубів із композиту «Charisma», 99,7 \% - 3 композиту «Dipol» та 99,2 \% - «Esta-3». Крайова адаптація, відповідність кольору, відсутність чутливості та шороховатості збережені у матеріалах
«Charisma» та «Dipol» повністю (100\%). У 2,6 \% реставрацій із композиту «Charisma» та 5,8 \% 3 «Dipol» виявлено незначну зміну кольору на межі між тканинами зуба та композитом, а у пломб з матеріалу «Esta-3» була незначна шороховатість $-1,8 \%$.

У дітей із задовільною гігієною порожнини рота порушення анатомічної форми та шороховатість частіше виявлено в реставраціях із композиту «Dipol» (2,9 і 2,7 \%) порівняно 3 матеріалами "Charisma» та «Esta-3». Окрім того, появу темної пігментації між

таблищя 1. Стан пломб із композиційного матеріалу «Charisma» (у \%) з різним рівнем гігієни порожнини рота за критеріями Ryge

\begin{tabular}{|c|c|c|c|c|c|c|c|c|c|c|c|c|}
\hline \multirow[t]{2}{*}{ Гігієна } & \multicolumn{2}{|c|}{$\begin{array}{c}\text { Анатомічна } \\
\text { форма }\end{array}$} & \multicolumn{2}{|c|}{$\begin{array}{l}\text { Крайова } \\
\text { адаптація }\end{array}$} & \multicolumn{2}{|c|}{$\begin{array}{c}\text { Шороховатість } \\
\text { поверхні } \\
\end{array}$} & \multicolumn{2}{|c|}{$\begin{array}{c}\text { Відповідність } \\
\text { кольору }\end{array}$} & \multicolumn{2}{|c|}{ Дискомфорт } & \multicolumn{2}{|c|}{$\begin{array}{c}\text { Крайова зміна } \\
\text { кольору }\end{array}$} \\
\hline & $\mathrm{A}$ & B & $\mathrm{A}$ & $\mathrm{B}$ & $\mathrm{A}$ & B & $\mathrm{A}$ & $\mathrm{B}$ & A & $\mathrm{B}$ & A & B \\
\hline Хороша & 98,9 & 1,1 & 100 & - & 100 & - & 100 & - & 100 & & 97,4 & 2,6 \\
\hline Задовільна & 98,8 & 1,2 & 97,1 & 2,9 & 98,5 & 1,5 & 97,5 & 2,5 & 94,5 & 5,5 & 98,2 & 1,8 \\
\hline Незадовільна & 99,2 & 0,8 & 98,8 & 1,2 & 97,7 & 2,3 & 99,3 & 0,7 & 98,5 & 1,5 & 98,3 & 1,7 \\
\hline Погана & 97,7 & 2,3 & 96,5 & 3,5 & 96,9 & 3,1 & 97,1 & 2,9 & 98,2 & 1,8 & 97,3 & 2,7 \\
\hline
\end{tabular}

Таблиця 2. Стан пломб із композиційного матеріалу «Dipol» (y \%) з різним рівнем гігієни порожнини рота за критеріями Ryge

\begin{tabular}{|c|c|c|c|c|c|c|c|c|c|c|c|c|}
\hline \multirow{2}{*}{ Гігієна } & \multicolumn{2}{|c|}{$\begin{array}{c}\text { Анатомічна } \\
\text { форма }\end{array}$} & \multicolumn{2}{|c|}{$\begin{array}{c}\text { Крайова } \\
\text { адаптація }\end{array}$} & \multicolumn{2}{|c|}{$\mid \begin{array}{c}\text { Шороховатість } \\
\text { поверхні }\end{array}$} & \multicolumn{2}{|c|}{$\begin{array}{c}\text { Відповідність } \\
\text { кольору }\end{array}$} & \multicolumn{2}{|c|}{ Дискомфорт } & \multicolumn{2}{|c|}{$\begin{array}{c}\text { Крайова зміна } \\
\text { кольору }\end{array}$} \\
\hline & A & B & A & $\mathrm{B}$ & A & $\mathrm{B}$ & $\mathrm{A}$ & $\mathrm{B}$ & A & B & $\mathrm{A}$ & $\mathrm{B}$ \\
\hline Хороша & 99,7 & 0,3 & 100 & - & 100 & - & 100 & - & 100 & - & 94,2 & 5,8 \\
\hline Задовільна & 97,1 & 2,9 & 97,1 & 2,9 & 97,3 & 2,7 & 97,5 & 2,5 & 95,9 & 4,1 & 95,6 & 4,4 \\
\hline Незадовільна & 96,2 & 3,8 & 91,3 & 8,7 & 95,2 & 4,8 & 95,3 & 4,7 & 98,3 & 1,7 & 83,6 & 16,4 \\
\hline Погана & 93,1 & 6,9 & 94,2 & 5,8 & 91,4 & 8,6 & 89,4 & 10,6 & 97,3 & 2,7 & 82,3 & 17,7 \\
\hline
\end{tabular}


Дитяча стоматологія

Таблищя 3. Стан пломб із композиційного матеріалу «Еsta-3» (у \%) з різним рівнем гігієни порожнини рота за критеріями Ryge

\begin{tabular}{|c|c|c|c|c|c|c|c|c|c|c|c|c|}
\hline \multirow[t]{2}{*}{ Гігієна } & \multicolumn{2}{|c|}{$\begin{array}{c}\text { Анатомічна } \\
\text { форма }\end{array}$} & \multicolumn{2}{|c|}{$\begin{array}{c}\text { Крайова } \\
\text { адаптація }\end{array}$} & \multicolumn{2}{|c|}{$\begin{array}{c}\text { Шороховатість } \\
\text { поверхні }\end{array}$} & \multicolumn{2}{|c|}{$\begin{array}{c}\text { Відповідність } \\
\text { кольору }\end{array}$} & \multicolumn{2}{|c|}{ Дискомфорт } & \multicolumn{2}{|c|}{$\begin{array}{c}\text { Крайова зміна } \\
\text { кольору }\end{array}$} \\
\hline & A & B & $\mathrm{A}$ & B & $\mathrm{A}$ & B & A & B & A & B & A & B \\
\hline Хороша & 99,2 & 0,8 & 99,0 & 1,0 & 98,2 & 1,8 & 99,9 & 0,1 & 100 & - & 100 & \\
\hline Задовільна & 98,2 & 1,8 & 96,4 & 3,6 & 97,9 & 2,1 & 97,8 & 2,2 & 95,3 & 4,7 & 98,1 & 1,9 \\
\hline Незадовільна & 95,1 & 4,9 & 98,3 & 1,7 & 91,6 & 8,4 & 89,3 & 10,7 & 97,4 & 2,6 & 91,1 & 8,9 \\
\hline Погана & 94,1 & 5,9 & 95,2 & 4,8 & 95,5 & 4,5 & 92,3 & 7,7 & 96,5 & 3,5 & 89,1 & 10,9 \\
\hline
\end{tabular}

пломбою та емаллю частіше діагностовано в реставраціях із композиту «Dipol» $(4,4 \%)$, порівняно 3 «Charisma» $(1,8 \%)$ та «Esta-3» $(1,9 \%)$. Суттєва різниця була між матеріалами при аналізі критерію дискомфорт. Незначна чутливість зубів, які запломбовані композитом «Charisma», виявлена значно частіше $(5,5 \%)$ порівняно 3 «Esta-3» (4,7 \%) та «Dipol» $(4,1 \%)$. Вагомим недостатком реставрацій є цілісність анатомічної форми. Невідповідність між пломбою та тканинами зуба (крайова адаптація), поява незначних тріщин діагностовано в зубах, каріозні дефекти яких відновлені композитами «Dipol» (2,9 \%) та «Esta-3» (3,6 \%).

У дітей із незадовільною гігієною порожнини рота в середньому збільшується кількість зубів з порушенням анатомічної форми реставрацій із композиту «Dipol» в 1,3 раза, а «Esta-3» - у 2,0 раза у порівняно з дітьми з задовільною гігієною порожнини рота. Значне збільшення кількості зубів виявлено з порушенням крайової адаптації, а особливо 3 композиту «Dipol» (8,7 \%), що характеризувалося появою незначних тріщин, в яких фіксувався зонд. Наявність тріщин провокувало появу пігментацій, що також частіше діагностовано в зубах, відновлених композитом «Dipol» $(16,4 \%)$, особливо порівняно 3 "Charisma» (1,7 \%). Збільшилась кількість зубів із шороховатістю поверхні та зміною кольору реставрацій у дітей із незадовільною гігієною порожнини рота порівняно $з$ дітьми з задовільною та хорошою гігієною порожнини рота. Найбільша кількість зубів в середньому 3 незначною шороховатістю поверхні пломб діагностовано 3 композиту «Esta-3» (8,4 \%). Кількість пломб із матеріалів «Dipol» та «Charisma» $з$ наявністю шороховатості відрізнялась незначно. Суттєва різниця виявлена при оцінці кольору реставрацій. Невідповідність кольору та порушення прозорості діагностовано в пломбах із композиту «Esta-3»
(10,7 \%) та «Dipol» (4,7 \%), що значно частіше порівняно 3 «Charisma» (0,7 \%).

У дітей із поганою гігієною порожнини рота показники якості пломб погіршені для всіх матеріалів порівняно 3 дітьми із хорошою та задовільною гігієною порожнини рота. Особливо збільшується кількість зубів з порушенням крайової адаптації, невідповідністю кольору, дискомфортом та крайовою пігментацією. Слід зауважити, що порушення анатомічної форми реставрацій (6,9 \%), поява шороховатості (8,6 \%), порушення кольору (10,6 \%) та поява пігментацій $(17,7$ \%) значно частіше виявлені в каріозних дефектах, відновлених матеріалом «Dipol». При поганій гігієні порожнини рота більш часто діагностовано порушення анатомічної будови реставрацій із композиту «Charisma» (2,3 \%) та матеріалу «Esta-3» (5,9 \%) порівняно 3 дітьми з хорошою та задовільною гігієною порожнини рота.

Висновки. Оцінка якості реставрацій жувальної групи зубів композитними матеріалами показала, що рівень гігієни порожнини рота суттєво впливає на якість пломб. Особливо при незадовільній та поганій гігієні порожнини рота, значно частіше з'являється крайова пігментація на межі реставрації та твердих тканин зубів, що може свідчити про інтенсивне утворення зубного нальоту та недостатню якість полірування поверхні. Окрім того, у дітей із незадовільною гігієною порожнини рота зустрічається невідповідність кольору та прозорості, що, на нашу думку, пов’язано $з$ активним утворенням зубного нальоту. Тому перед проведенням реставрацій обов'язково потрібно проводити професійну гігієну порожнини рота та систематичні контрольні огляди дітей (2-3 рази на рік), під час яких необхідно проводити гігієнічні заходи та навчання дітей гігієні порожнини рота з використанням індикаторів зубного нальоту, а також шліфування та полірування поверхні реставрації. 


\section{Список літератури}

1. Иванова Г. Г. Проблема краевого прилегания пломб и возможности ее решения в стоматологической клинике / Г. Г. Иванова // Клиническая стоматология. - 2003. -№ 1. - С. 63-64.

2. Николаев А. И. Унификация техники препарирования полостей и обработки реставраций при восстановлении зубов композитами / А. И. Николаев, Л. А. Лобовкина // Новое в стоматологи. - 2008. № 2. - С. 39-41.

3. Удод А. А. Оценка качества реставрационних работ в зависимости от уровня гигикни полости рта / А. А. Удод // Современная стоматология. - 2001. № 3. - С. 70-71.

4. Елистратова М. Краевая проницаемость пломб из различных пломбировочных материалов в ранних сроках лечения / М. Елистратова // Стоматология. 1998. - № 1. - С. 16-18.

5. Горегляд А. А. Сравнительные результаты пломбирования светоотверждаемыми композитами

\section{References}

1. Ivanova, G.G. (2009). Problema kraevogo prilagania plomb i vozmozhnosti ego resheniya $\mathrm{V}$ stomatologicheskoy klinike [The problem of the boundary attachment of seals and the possibility of solving it in a dental clinic]. Klinicheskaya stomatologiya - Clinical Dentistry, (1),63-64 [in Russian].

2. Nikolaev, A.I., \& Lobovkina, L.A. (2008) Unifikatsiya tekhniki preparirovaniya polostey i obrobotki restavratsyy pri vostanovlenii zubov kompozitami [Unification of the technique of cavity preparation and treatment of restorations during restoration of teeth by composites]. Novoe v stomatologii - New in Stomatology, (2), 39-41[in Russian].

3. Udod, A. A. (2001). Otsenka kachestva restavratsionnykh robot v zavisimosti ot urovnya gigieny polosti rta [Assessment of the quality of restoration work, depending on the level of oral hygiene]. Sovremennaya stomatologia - Modern Stomatology, (3), 70-71 [in Russian].

4. Elistratova, M. (1998). Kraevaya pronitsaemost plomb iz razlichnykh plombirovochnykh materialov v rannie sroki lecheniya [Marginal permeability of seals from при лечении болезней твердых тканей зубов / А. А. Горегляд // Стоматол. журн. - 2010. - Т. 11, № 2. C. $129-134$.

6. Ryge G. Clinical Criteria / G. Ryge // Int. Dent. J. -1980. Vol. 30. - P. 347-358.

7. Hickel R. Recommendations for conducting controlled clinical studies of dental restorative materials / R. Hickel, J-F. Roulet, S. Bayne // Int. Dent. J. - 2007. Vol. 57. - P. 300-302.

8. Devoto Walter. Composite in everyday practice: how to choose the right material and simplify application techniques in the anterior teeth / Devoto Walter, Saracinelli Monaldo, Manauta Jordi // Eur. J. of Esthetic Dentistry. - 2010. - № 1. - P. 102-125.

9. Memarpour Mahtab. Restoration of primary anterior teeth using intracanal polyethylene fibersand composite: AnIn Vivo Study / Memarpour Mahtab, Shafiei Fereshteh // The J. of Adhesive Dentistry. - 2013. Vol. 15, № 1. - P. 85-91.

various filling materials in the early treatment periods]. Stomatologia - Stomatology, (1), 16-18 [in Russian].

5. Gorgelad, A.A. (2010). Sravnitelnye rezultaty plombirovanie svetlootverzhdaemye compositami pri lechenii bolezney tverdykh tkaney zubov [Comparative results of sealing by light-curing composites in the treatment of diseases of hard tissues of teeth]. Stomatologicheskiy zhurnal - Stomatological Journal, 11 (2), 129-134 [in Russian].

6. Ryge, G. (1980). Clinical Criteria. Int Dent., 30, 347-358. 7. Hickel, R., Roulet, J., \& Bayne, S. (2007). Recommendations for conducting controlled clinical studies of dental restorative materials. Int. Dent. J., 57, 300-302.

8. Devoto, W., Monaldo, S., \& Jordi M. (2010). Composite in everyday practice: how to choose the right material and simplify application techniques in the anterior teeth. Eur. J. of Esthetic Dentistry, (1), 102-125.

9. Memarpour, M., \& Fereshteh S., (2013). Restoration of primary anterior teeth using intracanal polyethylene fibersand composite: AnIn Vivo Study. The J. of Adhesive Dentistry, 15 (1), 85-91. 